p-ISSN : 2541-2345, e-ISSN : 2580-8842

\title{
TORT VICTIM'S ABILITY TO PROFIT FROM THE PROCEEDS OF INSOLVENT TORTFEASOR'S LIABILITY INSURANCE
}

\author{
Yasser Mandela', I Ketut Dharma Putra Yoga ${ }^{2}$ \\ ${ }^{1}$ Leiden Law School, Leiden University \\ ${ }^{2}$ Budidjaja International Lawyers \\ iketutdharmapy@gmail.com
}

\begin{abstract}
This article describes and examines whether the tort victim can profit from the proceeds of the tortfeasor's liability insurance. This article aims to reflect on which approach, either in common or civil law, provides more access for the tort victim to profits from the proceeds of insolvent tortfeasor's liability insurance policy. The method used in this research is comparative research. The result of this research showed that the status of insurance proceeds becomes debatable because the tort victim (as the claimant) will have no better rights than any other unsecured creditors during insolvency proceedings. This is regardless of the fact that the tortfeasor already got a fund, albeit indirectly through the insurer, to compensate the tort victim's losses. In relation to this issue, the United Kingdom has adopted the Third Parties (Rights against Insurers) Act 2010 which gives right for tort victim to directly claim for compensation against tortfeasor's liability insurer in the event of tortfeasor's insolvency. Meanwhile, the Indonesian legal system provides no clear legal protection to the tort victim. Thus, in the event of insolvency, the tort victim cannot obtain compensation from the insurer, but only from tortfeasor's bankruptcy estate as part of creditors' debts. Furthermore, as an unsecured creditor, the tort victim will obtain the debtor's bankruptcy estate after all secured creditors have received their payment.
\end{abstract}

Keywords: tort victim; insolvency; liability insurance 


\section{INTRODUCTION}

\section{A. Background}

One of the functions of liability insurance is to indemnify the person suffering damages (e.g., the injured, tort victim). ${ }^{1}$ In an ideal situation, if the insured committed a tortious act, he can turn to his liability insurer to indemnify the losses of the tort victim, or in other words, the tort victim can profit from the liability insurance proceeds payable from the policy. ${ }^{2}$ However, a problem arises when the insured becomes insolvent before compensating for the tort victim's losses. In such an event, the status of insurance proceeds becomes debatable because, for example in the common law, the tort victim (as the claimant) will have no better rights than any other unsecured creditors. This is regardless of the fact that the insured/tortfeasor already got a fund, albeit indirectly through the insurer, to compensate for the tort victim's losses. ${ }^{3}$

Previous studies reported that the legal tools developed to approach this issue shall vary depending on the relevant jurisdiction. Some jurisdictions found a solution by developing entirely new legislation outside insolvency law, e.g., the United Kingdom (UK). ${ }^{4}$ While the others, by assessing the issue in a case per case basis, e.g., the United States. ${ }^{5}$ Unfortunately, some jurisdiction, like Indonesia, does not even have an advanced discussion on this issue and merely discuss the position of tort in bankruptcy proceedings. ${ }^{6}$

From the above, it is clear that there is a gap of knowledge from the Indonesian law perspective in the issue related to tort victim's ability to profit from the proceeds of insolvent tortfeasor's liability insurance. Moreover, none of the previous studies have discussed which kind of approach is friendlier toward the tort victim in the event of tortfeasor's insolvency. Such gaps, which will be researched further in this article, shall distinguish and become the novelty point of this article from any of the previous studies.

${ }^{1}$ Willem van Boom, Comparative Insurance Law, International Tort and International Insurance Law course, Leiden University, Netherlands, January - February 2020, p. 120.

${ }^{2}$ Ibid.

${ }^{3}$ Chris Nicoll, Third Party Rights Against Insurers: Time for Another Look?, New Zealand Business Law Quarterly, 2016, p. 259.

${ }^{4}$ Ibid.

${ }^{5}$ Howard Seife, Insurance Proceeds in Bankruptcy, Banking Law Journal, 2002, p. 699.

${ }^{6}$ Wibisono Adithyo Yudho, Perbuatan Melanggar Hukum Sebagai Sumber Utang Dalam Undang-Undang Nomor 17 Tahun 2004 tentang Kepailitan dan Penundaan Kewajiban Pembayaran Utang, Madura: Rechtidee, Fakultas Hukum Universitas Trunojoyo Madura, 2017, p. 215-219. 
This article aims to reflect on which approach provides more access for the tort victim to profits from the proceeds of insolvent tortfeasor's liability insurance policy. In other words, the authors intend to search which approach is friendlier toward the tort victim. Towards this end, a comparative legal analysis is used. To decide which system should be compared, the following has been considered. UK law is chosen because it has long adopted the specific rules - with the recent new updates - concerning tort victim's rights during tortfeasor's insolvency. Indonesian law, on the contrary, is still relying on a more general civil law rule to resolve this issue. As of now, the UK approach seems the more victim-friendly because it allows the tort victim to directly claim compensation against the insurer in the event of the insured's insolvency and provides significant protection for the tort victim to avoid unfair procedural defense by the insurer to reject the tort victim's claim. ${ }^{7}$

This paper will proceed in three parts. The first part will discuss the concept of liability insurance and its relations with the tort victim. The second part will discuss the position of tort victim during insolvency proceedings. Before concluding remarks, the third part will discuss the approaches taken by UK and Indonesia in distributing liability insurance proceeds in the event of tortfeasor's insolvency. Throughout this paper, the word 'tortfeasor', 'insured', and 'debtor' will be used interchangeably to describe the insolvent tortfeasor who is covered by a liability insurance policy.

\section{B. Problems}

Based on the background of the issue explained above, the authors are hereby interested to further analyze the relationship between tort victim and tortfeasor's liability insurer in the event of tortfeasor's insolvency, with the title: Tort Victim's Ability to Profits from the Proceeds of Insolvent Tortfeasor's Liability Insurance.

Therefore, the authors express the problems set forth in the following problems' formulation:

1. What kind of legal relationship that governs the tort victim and tortfeasor's liability insurer?

2. How is the position of tort victim during insolvency proceedings?

3. Between UK and Indonesia legal system, which approach provides more access for the victim to profits from insolvent tortfeasor's liability insurance proceeds?

\section{Methods}

The method used in this research is comparative research. A comparative research is a research comparing one or more variables with two

\footnotetext{
${ }^{7}$ Wenette Jacobs, The Third-Party Plaintiff's Exceptional Direct Claim against the Insured Defendant's Liability Insurer: Some Lessons to Be Learnt from the Third Parties (Rights against Insurers) Act 2010 in English Law, South African Mercantile Law Journal, 2010, p. 608.
} 
or more different samples, or two different times. ${ }^{8}$ In applying this method, this research is used to understand and analyse the distinction between UK and Indonesia legal system in relation to the position of tort victim and and tortfeasor's liability insurer in the event of tortfeasor's insolvency issue.

\section{RESULTS AND DISCUSSION}

A. Liability Insurance and its relation with Tort Victim

(i) Liability Insurance

Nowadays, the insurance market has grown a lot that almost every risk in our life can be protected with insurance coverage. Be it a risk upon potential health problem, vehicle accident or legal fees due to dispute with the third party, the insurance company usually already has an insurance product with coverage tailored according to the needs of potential insured. ${ }^{9}$ From those large numbers of products, generally, coverage of insurance can be distinct between 'first-party' and 'third party' insurance. First-party insurance serves the interest of the policyholder or insured, while third-party insurance covers the liability of the insured. ${ }^{10}$ Due to the nature of its coverage, third-party insurance is usually also referred to as 'liability insurance'.

Like other kinds of insurance, in order to get it risks covered, the insured must first enter into a contract - usually called policy - with the liability insurer. Van Boom defined liability insurance contract as 'an indemnity insurance against the risk of liability in tort or contract'. ${ }^{11}$ Generally, liability insurance serves two functions. The first function relates to the right of tort victim to obtain a recovery for damages occurred due to the insured's action. This function can also be called indemnity function toward third parties because it aims to ensure compensation toward the person suffering damages (e.g., the injured or tort victim). ${ }^{12}$ The second and primary function is related to potential debt that may incur to the insured. In other words, liability insurance aimed to protect the insured's assets if the insured is held liable due to the occurrence of an insured event. ${ }^{13}$

\footnotetext{
${ }^{8}$ Sugiyono, Metode Penelitian Pendidikan Pendekatan Kuantitatif, Kualitatif, dan R\&D,
} Bandung: Alfabeda, 2014, p. 54.

${ }_{9}^{9}$ Malcolm Clarke, An introduction to insurance contract law, in Julian Burling and Kevin Lazarus (eds), Research Handbook on International Insurance Law and Regulations, Edward Elgar Publishing, 2012, p. 3-5.

${ }^{10}$ Willem van Boom, Op., Cit., p. 5.

11 Ibid, p. 119.

${ }^{12}$ Ibid, p. 121.

${ }^{13} \mathrm{Ibid}$, p. 120. 
Depending on the actual coverage in the policy, the second function may create two duties for the insurer, which are duty to indemnify and duty to defend. With a duty to indemnify, the insurer is required to indemnify any losses that may be occurred to the insured due to the occurrence of insured event. While with duty to defend, the insurer will be obliged to cover the costs that occurred to defend the insured against third party claim. ${ }^{14}$

Albeit not always explicitly specified, these two duties usually can be found in statutory provision related to liability insurance. For example, Germany Insurance Contract Act (Versicherungsvertragsgesetz - VVG) explicitly mentions both duties in its definition of liability insurance. ${ }^{15}$ The Indonesian Insurance $\mathrm{Law}^{16}$ - which does not give a specific definition of liability insurance - on the other hand only explicitly mention a duty to indemnify when defining insurance contract. ${ }^{17}$ Although it is unclear why duty to defend is absent in Indonesian Insurance Law, such absence should be fair and reasonable if we see it from the perspective of the insurer. Under the Indonesian legal system, it is not possible to claim for the recovery of legal fees. ${ }^{18}$ Thus, if the insurer has a duty to defend, the amount spent to defend the insured during court proceedings will not be recoverable at all even if the court decision is in favor of the insured instead of the tort victim. Nonetheless,

15 Art. 100 of VVG reads as follows: 'In liability insurance, the insurer is under a duty to indemnify the policy holder for any claims brought by a third party based on the policyholder's responsibility for a fact arising during the period of insurance, and to defend the insured against unfounded claims.'

${ }^{16}$ Law No. 40 of 2014 on Insurance.

${ }^{17}$ Art. 1 point (1) of Indonesian Insurance Law reads as follows:

'Insurance is an agreement between two parties, namely the insurance company and the policy holder, which becomes the ground for the receipt of premium byt the insurance company as an exchange for:

a. providing compensations to the insured or policy holder due to loss, damage, incurring cost, profit loss or legal liability towards third parties which may be suffered by the insured or policy holder due to an uncertain event; or

$b$. providing payments on the basis of the death of the insured or a payment on the basis of the life of the insured with a benefit of which value has been determined and/or based on the result of fund management.'

${ }^{18}$ Supreme Court of Indonesia Decision No. 635 K/Sip/1973 dated 4 July 1974.
} 
as per the freedom of contract principle adopted by the Indonesian Civil Code, ${ }^{19}$ the absence of a duty to defend in Indonesian Insurance Law does not mean that the parties will not be able to agree for coverage upon legal defense in the insurance policy.

(ii) Relation between Liability Insurer and Tort Victim

From the above explanation, it can be seen that in general liability insurance involves at least three parties: (i) the insurer; (ii) the insured; and (iii) the tort victim. To understand the relationship between the liability insurer and tort victim, it is important to first assess the relationship between liability insurance and tort law itself. Theoretically, there is no relation between them because they are two entirely different fields of law. In reality, however, the relationship is more complicated as tort liability is sometimes a matter that must be resolved by liability insurer and tort victim. ${ }^{20}$ Specifically, both subjects are closely connected because most of the tort case involves legal action that can be covered by liability insurance. ${ }^{21}$

Although it seems that in reality there is indeed a relation between liability insurer and the tort victim, such relation is still vague and problematic because each of them only has a legal relationship with the insured/tortfeasor, not to each other. The tortfeasor's legal relationship with the insurer is established via the insurance policy, while the relationship with tort victim is established via tort. Thus, traditionally the tort victim would not be able to bypass the insured to directly file a tort claim against the insurer. Also, due to privity of contract principle adopted by many jurisdictions, it may also not possible for the tort victim to file a breach of contract claim against the insurer because he is not a party to the insurance policy. Pursuant to privity of contract principle, unless stated otherwise in the contract - and pursuant to the statutory provision of the relevant jurisdiction - the effect of a contract shall be limited to the parties of the contract. ${ }^{22}$ To overcome this problem, some jurisdictions have developed a new system where it is possible for the tort victim to directly claim against the insurer. ${ }^{23}$ This issue will be further discussed in Section II (C) below by providing an example of jurisdiction that allows such new system.

\footnotetext{
${ }^{19}$ Article 1338 of Indonesian Civil Code.

${ }^{20}$ Ina Ebert, Tort Law and Insurance, in Mauro Bussani and Anthony J. Sebok (eds), Comparative Tort Law Global Perspective, Edward Elgar Publishing, 2015, p. 144.

${ }^{21}$ Ebert, Ibid., in particular explain that without liability insurance, full compensation toward the victim for non-minor damage would 'always be an illusion'.

22 Ewan McKendrick, Contract Law Text, Cases and Materials, England: Oxford University Press, 2012, p. 5.

${ }^{23}$ See for example, the UK Third Parties (Rights Against Insurers) Act 2010.
} 


\section{B. Position of Tort Victim during Insolvency Proceedings}

(i) Characteristic of Insolvency Proceedings

Insolvency or bankruptcy is an inability to pay the debts to the creditor. In the other words, bankruptcy is a collective procedure for the recovery of debts by creditors. ${ }^{24}$ Broadly speaking, the essential features of bankruptcy proceedings is (i) each creditor has a right over the debtor's bankruptcy estate, but the execution upon the assets are stayed and replaced by a right to claim for its respective dividend; (ii) all of the assets of the bankrupt are available for creditors; (iii) creditors are paid pari passu, which is pro rata out of the assets according to their claims. In principle, above all, the law shall basically deal with the procedural matters in the bankruptcy proceedings. For example, the bankruptcy should be advertised/ announce publicly so that the creditors know the circumstances, and then also, the liquidator/curator must get in the assets, investigate the bankrupt's affairs, verify the creditor claims and distribute the proceeds to creditors based on the amount of claims. ${ }^{25}$

To extend our understanding on bankruptcy, in some jurisdictions, there is a difference between the term 'insolvency' and 'bankruptcy'. For example, the Indonesian legal system only regulates provision related to bankruptcyrather than insolvency proceedings. The law indeed give definition of insolvency, which is a condition of debtor's inability to pay any debts to all creditors $^{26}$, or in the other words, the debtor will be deemed insolvent if the debts exceed the total amount of its assets. ${ }^{27}$ However, the Indonesian law does not require a debtor to be in the state of insolvency in order to commence bankruptcy proceedings. ${ }^{28}$

Bankruptcy, which defined as general confiscation of all assets of a bankrupt debtor that will be managed and liquidated by a curator, ${ }^{29}$ only require a debtor to has two or more creditors that fails to pay at least one debt which is due and payable. ${ }^{30}$ Therefore, it is obvious that in order to declare

${ }^{24}$ Phillip R. Wood, Principle of International Insolvency (Part I), London: Sweet \& Maxwell, 1995, p. 95.

${ }^{25}$ Phillip R. Wood., Ibid., p. 96

${ }^{26}$ Elucidation to Article 57 paragraph (1) of Bankruptcy Law reads as follows: 'Insolvency" shall mean the condition of being unable to pay debts.'

${ }^{27}$ Sutan Remy Sjahdeini, Sejarah, Asas, dan Teori Hukum Kepailitan, Jakarta: Kencana Prenadamedia Group, 2016, p. 156.

${ }^{28}$ Article 2 paragraph (1) of Bankruptcy Law

${ }^{29}$ Article 1 paragraph (1) of Bankruptcy Law.

${ }^{30}$ Article 2 paragraph (1) of Bankruptcy Law. 
the debtor as bankrupt, such debtor total debts is not required to exceed the total amount of its assets (i.e. insolvent condition).

(ii) Status of Tort Victim During Insolvency Proceedings

To understand the status of tort victim during insolvency/bankruptcy proceedings, it is important to firstly comprehend the type of creditors existed in the bankruptcy case. Generally, there is a principle called structured creditors principle which commonly known in the bankruptcy's practice, which portrays the ranking of creditors; secured creditor, preferred creditor and unsecured creditor. ${ }^{31}$

Secured creditor is a creditor whose interests are secured by an in rem right is usually entitled to cause the foreclosure of the collateral, without a judgment and with priority over the other creditors. ${ }^{32}$ Further, preferred creditor is a creditor who has preference to its claim, wherein the preference issue is only relevant if there is more than one creditor and assets are not sufficient to pay all creditors. ${ }^{33}$ Meanwhile, unsecured creditor is a creditor who has no priority and will therefore be paid, if any proceeds of bankruptcy estate remain. ${ }^{34}$ Thus being said, if the tort victim does not have any security attached toward the tortfeasor's claim - for example security as an accessory of tort settlement agreement - or if the jurisdiction that governs insolvency proceedings does not classify the tort victim as preferred creditor, naturally the status of tort victim is merely an unsecured creditor.

Aside of such structured creditors principle, there is also a principle called pari passu prorata parte principle which determines the proceeds of debtor's bankruptcy estate distribution. Pari passu prorata parte principle means that that the debtor's assets are a collective security for the creditors, including for the tort victim, and the proceeds of bankruptcy estate shall be distributed proportionally to the creditors ${ }^{35}$, unless the there is a creditor whose the payment of the receivables should be prioritized or preferred. ${ }^{36} \mathrm{On}$ the similar note, this principle provides a proportional assets distribution,

${ }^{31}$ M. Hadi Shubhan., Op. Cit.,. p. 32.

32 Jerry Hoff, Indonesian Bankruptcy Law, Jakarta: Tatanusa, 1999, p. 96 in M. Hadi Shubhan, Hukum Kepailitan: Prinsip, Norma dan Praktik di Peradilan, Jakarta, Kencana Prenadamedia Group, 2008, p. 32.

${ }^{33}$ M. Hadi Shubhan., Ibid.

${ }^{34}$ M. Hadi Shubhan., Ibid.

${ }^{35}$ Article 1132 of Indonesian Civil Code.

legal order of priority among the creditors.'

${ }^{36}$ Kartini Muljadi, Actio Pauliana dan Pokok-Pokok tentang Pengadilan Niaga in the Hukum Kepailitan: Prinsip, Norma dan Praktik di Peradilan by M. Hadi Shubhan, 2001, p. 29. 
where the creditors who have receivables that are greater than other creditors, will get a larger portion of the payment. ${ }^{37}$ Nevertheless, the proportionality of the payment distribution to the creditors will not only depend on how much receivables that the creditors have, but also the status of the creditors whether they are secured, preferred or unsecured creditors - this hierarchy of creditors is crucial to be considered as it will determine which creditor who has the highest ranking in terms of status upon the debtor bankruptcy estate and which ones are the weakest.

As an example, Indonesian law does not specifically regulate the tort victim's rights upon the debtor's bankruptcy estate, including legal remedies that can be taken by the tort victim to pursue their rights toward the debtor's bankruptcy estate. However, if we were to classify the position of tort victim during bankruptcy proceedings, it is obvious that the tort victim shall be classified as an unsecured creditor because the tort victim's qualification as a tort-based creditor is not fitted with the general requirements of secured and preferred creditors. Even if there is a possible case where the tort victim already signed a settlement agreement that contains with security over certain assets - which would then classify him as a secured creditor - arguably, such debt arising from the settlement agreement would be considered as a contractual debt rather than tort debt. Therefore, as an unsecured creditor, the tort victim shall have no priority over any of the bankruptcy estate. ${ }^{38}$

Basically, under Indonesian laws, the three types of creditors have been clearly defined. The secured creditor is the holder of mortgage, pledge, hypothec and other securities. ${ }^{39}$ The preferred creditor shall be prioritized over the other creditors as it is regulated by the laws, for the example is tax collection. $^{40}$ Lastly, the unsecured creditor ranked the lowest position compared to the other creditors, thus, this creditor will not be prioritized during the distribution of bankruptcy estate. ${ }^{41}$

Theoretically, the secured creditor may execute their right over the debtor's assets as if no bankruptcy occurred. ${ }^{42}$ However, such right shall be stayed for a time period of at most 90 (ninety) days since the date of the decision declaring the bankruptcy of the creditor is rendered. ${ }^{43}$ Furthermore,

${ }^{37}$ M. Hadi Shubhan, Op., Cit., p. 30

${ }^{38}$ M. Hadi Shubhan, Ibid., p. 32

${ }^{39}$ Article 1133 in conjunction with Article 1134 of Indonesian Civil Code and Article 55 paragraph (1) of Bankruptcy Law.

${ }^{40}$ Article 1139 in conjunction with the Article 1149 of Indonesian Civil Code and Article 21 paragraph (1) and (3) of Bankruptcy Law.

${ }^{41}$ Article 1131 and Article 1132 of Indonesian Civil Code.

42 Article 55 paragraph (1) of Bankruptcy Law.

${ }^{43}$ Article 56 paragraph (1) of Bankruptcy Law. 
philosophically this stay provision is applied to avoid the holder of collateral rights to sell the assets quickly with an unreasonable price (below the market's price). Such a sale strategy is only to satisfy the interest of the said secured creditor. On the other hand, if the execution right to sell the debtor's assets is stayed for 90 (ninety) days, it will provide an opportunity for the curator to sell the assets at the best price and mutually beneficial for all parties. Thus, if the sale of proceeds exceeds the receivables held by the creditor, the remaining proceeds can be returned to the bankruptcy estate. ${ }^{44}$ This concept, basically, champions the rights of the debtor upon their assets - to obtain the proceeds/liquidation value as much as possible in fair way.

Notwithstanding the amount of tort victim's claims toward the debtor, the tort victim will obtain the debtor's bankruptcy estate after all secured creditors have received their payment. Consequently, in worst scenario, there is a huge possibility that the tort victim will fails to obtain full recovery of its claim in case the debtor's bankruptcy estate have been wholly paid to the secured and preferred creditors.

\section{Tort Victim's Ability to Profits from Liability Insurance Proceeds}

(i) The UK Approach

The recently enforced UK Third Parties (Rights Against Insurers) Act $2010(2010 \mathrm{Act})^{45}$ provides a rather straightforward approach that enables the tort victim to directly claim against the insured's liability insurer in the event of the insured's insolvency. ${ }^{46}$ Such an approach is understandable as, according to Chris Nicoll, the 2010 Act aim was to 'take the insured's claim outside of insolvency and make it self-sufficient, otherwise it would become part of the pool of unsecured creditors. ${ }^{47}$ Compared to the previously applicable 1930 Act $^{48}$ the 2010 Act provides better protection for the tort victim in the event of the insured's insolvency, as it allows the tort victim to claim against the insurer without first establishing the liability of insured. ${ }^{49}$ Thus, the tort victim may not involve the insured at all in any proceedings to obtain insurance proceeds.

\footnotetext{
${ }^{44}$ M. Hadi Shubhan, Op., Cit., p. 173.

${ }^{45}$ UK Third Parties (Rights Against Insurers) Act 2010 is came into force on 1 August 2016.

46 Section 1 of 2010 Act.

${ }^{47}$ Chris Nicoll, Loc., Cit., p. 259.

48 The enforcement of 2010 Act has repealed the applicability of the Third Parties (Rights against Insurers) Act 1930 (1930 Act) save from several special conditions as stated in Schedule 3 to 2010 Act

${ }^{49}$ Section 1(3) of 2010 Act.
} 
Moreover, the 2010 Act has also tackled several procedural issues that may hinder the tort victim from obtaining insurance proceeds, for example, issues related to the notification requirement. ${ }^{50}$ Under the 1930 Act regime, the tort victim shall have the same rights against the insurer as of the original contracting party (i.e., the insured). Consequently, after establishing the liability of insured, the tort victim must strictly follow any procedural conditions set in the policy to claim against the insurer, including the requirement to notify insurer on the occurrence of an insured event (i.e. the tort) within the designated period. This may lead to a failure claim by the tort victim because the insured may not be able to notify the insurer on the occurrence of tort once it becomes insolvent. This issue solved in 2010 Act which in essence stipulates that despite the insurer may rely on defense against the tort victim as if it is made against the insured, and there is no requirement for the tort victim to notify the insurer of the existence of claim under the insurance policy regardless such requirement is mandatory under the original insurance policy. ${ }^{51}$

Furthermore, similar with 1930 Act, 2010 Act also honors the existence of arbitration agreement within insurance policy even if the insured's rights have been transferred to the tort victim due to tort. ${ }^{52}$ Nonetheless, where under 1930 Act the tort victim must strictly litigate through arbitration when such arbitration agreement exists between the insured and insurer, the 2010 Act gives the ability for the tort victim to choose either litigating against the insurer via the previously agreed arbitration agreement or via the proceedings available as to the insured's liability against him. ${ }^{53}$

Lastly, the 2010 Act also gives the tort victim more access to information related to tortfeasor's liability insurance policy, which would be beneficial for him to claim recovery related to his damages. ${ }^{54}$ Most importantly, the 2010 Act provides the rights for the insurer can request relevant information related to tortfeasor's insurance policy from the tortfeasor itself or from another person who can provide the information. ${ }^{55}$

(ii) The Indonesia Approach

Neither Indonesian Bankruptcy Law ${ }^{56}$ nor Indonesian Insurance Law ${ }^{57}$ governs the ability of the tort victim to profits from the proceeds of the insured's liability insurance policy. The Indonesian Bankruptcy Law, in

${ }^{50}$ Alison Padfield, Insurance Claim, England: Bloomsbury, 2016, p. 21-22.

${ }^{51}$ Section 2(4) and 9(4) of 2010 Act.

${ }^{52}$ Section 2(2) and 2(7) of 2010 Act.

${ }^{53}$ Alison Padfield, Op.Cit., p. $22 \& 25$.

${ }^{54}$ Ibid., p. 26.

${ }^{55}$ Section 11 of 2010 Act.

${ }^{56}$ Law No. 37 of 2004 on Bankruptcy and Suspension of Obligation for Payment of Debts.

${ }^{57}$ Law No. 40 of 2014 on Insurance. 
particular, does not give any explanation of whether insurance proceeds shall be included in the bankruptcy estate. It only provides that in the event of bankruptcy, all of the debtor's estate shall be put into general confiscation to be distributed to the creditors. ${ }^{58}$

Despite such lack of explanation under Indonesian Bankruptcy Law, based on privity of contract principle adopted by Indonesian Civil Code ${ }^{59}$, it is clear that the tort victim would not be able to profit from the insured's insurance policy, as it is not the party under the contract and therefore does not have any legal relationship with the insurer. Consequently, the tort victim may only obtain compensation for its damages merely from the tortfeasor, not from the insurer.

In such an event, if the tortfeasor has been declared as bankrupt, to obtain compensation, the tort victim must join the bankruptcy proceedings as one of the creditors. However, such a tort victim must first establish that the tortfeasor is indeed has a debt against the tort victim. In other words, the tort victim must already obtain and subsequently present a final and binding court decision from a civil proceeding declaring the tortfeasor liability and debt against him when registering its debt to the bankruptcy proceedings. The tort victim may lose all of its claim against the tortfeasor if by the time of debt registration for bankruptcy proceedings, it could not present a court decision evidencing the tortfeasor's debt. ${ }^{60}$

From the above discussion, although it is clear that the currently the position of Indonesian law is to not provide access for tort victim to profits from insolvent tortfeasor's liability insurance proceeds, it is foreseeable that such position will probably not changing in the near future. This position can be seen from the discussion related to potential amendment to Indonesian Bankruptcy Law, of which does not seem to include this issue as part of amendment points. ${ }^{61}$

\section{CONCLUSION}

Based on the foregoing, although in reality their relation is closely connected, we found that theoretically there is no legal relation between tort victim and liability insurance. Each of them only has legal relationship with the tortfeasor/insured through tort (i.e., for tort victim) and contract (i.e., for

${ }^{58}$ Susanti Adi Nugroho, Hukum Kepailitan Di Indonesia: Dalam Teori dan Praktik Serta Penerapan Hukumnya, Jakarta: Prenadamedia Group, 2018, p. 32.

${ }^{59}$ Article 1340 of Indonesian Civil Code.

${ }^{60}$ Nindyo Pramono and Sularto, Hukum Kepailitan dan Keadilan Pancasila, Yogyakarta: ANDI, 2017, p. 247-249.

61 National Law Development Agency, Academic Draft of Bill of Law regarding the Amendment to Law No. 37 of 2004 on Bankruptcy and Suspension of Obligation for Payment of Debts, 2017, Jakarta: National Law Development Agency, Ministry of Law and Human Rights 
liability insurer). However, with new system introduced by the UK, it is possible for them to have legal relation through statutory provision under 2010 Act.

Furthermore, we also found that in insolvency proceedings, if the tort victim does not have any security attached toward the tortfeasor's claim - for example security as an accessory of tort settlement agreement - or if the jurisdiction that governs insolvency proceedings does not classify the tort victim as preferred creditor, the tort victim shall be treated as an unsecured creditor and shall have no better rights than the other unsecured creditors. However, the UK found a solution to this issue if the tortfeasor actually covered by liability insurance to indemnify the tort victim's losses. In such a condition, the insurance proceeds will not be treated as part of insolvency estate and the tort victim can directly his claim toward the insurer.

Lastly, it is clear that compared to Indonesia, the UK approaches provide more access for the tort victim to profits from the proceeds of insolvent tortfeasor's liability insurance policy. It is mainly because the 2010 Act allows the victim to directly claim against the insurer even after the tortfeasor already insolvent. The 2010 Act also takes extra miles in protecting the tort victim by (i) dismissing the insurer's defense through unfair procedural issues where the tort victim by default cannot rebut against, e.g., notification requirement; (ii) giving the options for the tort victim to choose forum other than the agreed arbitration forum in the insurance policy; and (iii) providing more access for the tort victim to obtain information related to tortfeasor's liability insurance.

For recommendation, we found that there is a lot of room for improvement in the Indonesian legislations related to tort victim's position in insolvency proceedings. Most importantly, rather than relying on a more general civil law provision, it would be more beneficial to the tort victim if the law can provide more clarity toward their rights in relation to liability insurance proceeds.

\section{REFERENCES}

\section{Book}

Ebert, Ina. (2012). Tort Law and Insurance. In Mauro Bussani and Anthony J. Sebok (eds), Comparative Tort Law Global Perspective, (Edward Elgar Publishing, pp. 144-150).

Clarke, Malcom. (2012). An introduction to insurance contract law. In Julian Burling and Kevin Lazarus (Ed.). Research Handbook on International Insurance Law and Regulations, (Edward Elgar Publishing, pp. 3-18).

McKendrick, Ewan. (2012). Contract Law Text, Cases and Materials. England: Oxford University Press.

Nugroho, Susanti Adi. (2018). Hukum Kepailitan Di Indonesia: Dalam Teori dan Praktik Serta Penerapan Hukumnya. Jakarta: Prenadamedia Group.

Padfield, Alison. (2016). Insurance Claim. England: Bloomsbury. 
Pramono, Nindyo and Sularto. (2017). Hukum Kepailitan dan Keadilan Pancasila. ANDI: Yogyakarta.

Shubhan, M. Hadi. (2008). Hukum Kepailitan: Prinsip, Norma dan Praktik di Peradilan. Jakarta: Kencana Prenadamedia Group.

Sjahdeini, Sutan Remy. (2016). Sejarah, Asas, dan Teori Hukum Kepailitan. Jakarta: Kencana Prenadamedia Group.

Wood, Phillip R. (1995). Principle of International Insolvency (Part I), London: Sweet \& Maxwell.

Sugiyono. (2014). Metode Penelitian Pendidikan Pendekatan Kuantitatif, Kualitatif, dan $R \& D$. Bandung: Alfabeta.

\section{Regulation}

Germany Insurance Contract Act 2008 (Versicherungsvertragsgesetz)

Law No. 37 of 2004 on Bankruptcy and Suspension of Obligation for Payment of Debts (Bankruptcy Law).

Law No. 40 of 2014 on Insurance (Insurance Law).

Supreme Court of Indonesia Decision No. 635 K/Sip/1973 dated 4 July 1974.

UK Third Parties (Rights Against Insurers) Act 1930.

UK Third Parties (Rights Against Insurers) Act 2010.

\section{Journal/Article}

Butarbutar, Elisabeth Nurhaini. (2019). Pembuktian Terhadap Perbuatan Debitur yang Merugikan Kreditur Dalam Tuntutan Actio Pauliana. Jakarta: Jurnal Yudisial, Komisi Yudisial, 12(2).

DOI: http://dx.doi.org/10.29123/jy.v12i2

Hardjaloka, Loura. (2015). Kepailitan Lintas Batas Perspektif Hukum Internasional dan Perbandingannya Dengan Instrumen Nasional di Beberapa Negara. Surabaya: Jurnal Yuridika, Fakultas Hukum Universitas Airlangga, 30(3).

Jacobs, Wenette. (2010). The third-party plaintiff's exceptional direct claim against the insured defendant's liability insurer: Some lessons to be learnt from the third parties (rights against insurers) act 2010 in english law. South African Mercantile Law Journal, 22(4).

Nicoll, Chris. (2016). Third Party Rights Against Insurers: Time for Another Look?. New Zealand Business Law Quarterly, 22.

Nola, Luthvi Febryka. (2017). Kedudukan Konsumen Dalam Kepailitan. Jakarta: Jurnal DPR RI, 8(2).

Nugroho, Aditya Aryo and Djuwityastuti. (2019). Klaim Asuransi Sebagai Dasar Adanya Utang Dalam Permohonan Kepailitan Perusahaan Asuransi (Studi Kasus: Putusan Nomor 408 K/Pdt-Pailit/2015). Surakarta: Jurnal Privat Law, 7(2).

Prayogo, Sedyo. (2016). Penerapan Batas-Batas Wanprestasi dan Perbuatan Melawan Hukum dalam Perjanjian. Semarang: Jurnal Pembaharuan Hukum, Universitas Islam Sultan Agung, 3(2). 
DOI: http://dx.doi.org/10.26532/jph.v3i2.1453

Prihatmaka, Hervana Wahyu, Sunarmi, Rahmad Hendra. (2014). Insolvensi dalam Hukum Kepailitan di Indonesia (Studi Putusan No. 48/ Pailit/2012/Pn.Niaga.Jkt.Pst antara PT. Telekomunikasi Selular vs PT. Primajaya Informatika). Lampung: Fiat Justitia Jurnal Ilmu Hukum, 8(2) DOI: https://doi.org/10.25041/fiatjustisia.v8no2.295

Seife, Howard. (2002). Insurance proceeds in bankruptcy. Banking Law Journal, 119(8)

Surjanto, Diana. (2018). Urgensi Pengaturan Syarat Insolvensi Dalam UndangUndang Kepailitan dan Penundaan Kewajiban Pembayaran Utang. Denpasar: Acta Comitas Jurnal Hukum Kenotariatan, 3(2).

DOI: https://doi.org/10.24843/AC.2018.v03.i02

Yudho, Wibisono Adithyo. (2017). Perbuatan Melanggar Hukum Sebagai Sumber Utang Dalam Undang-Undang Nomor 17 Tahun 2004 tentang Kepailitan dan Penundaan Kewajiban Pembayaran Utang. Madura: Rechtidee, Fakultas Hukum Universitas Trunojoyo Madura, 12(2).

DOI: https://doi.org/10.21107/ri.v12i2.3339 
p-ISSN : 2541-2345, e-ISSN : 2580-8842

\section{Others}

Boom, W.V. (2020). Comparative Insurance Law. Unpublished manuscript, International Tort and International Insurance Law course, Leiden University, Netherlands.

National Law Development Agency. (2017). Academic Draft of Bill of Law regarding the Amendment to Law No. 37 of 2004 on Bankruptcy and Suspension of Obligation for Payment of Debts. Jakarta: National Law Development Agency, Ministry of Law and Human Rights 